\title{
Processo e Cultura: Praxismo, Processualismo e Formalismo em Direito Processual
}

\author{
Daniel Francisco Mitidiero ${ }^{1}$
}

\begin{abstract}
Introdução; I - Experiência, Cultura e Direito Processual Civil; II Endereços Culturais e Modelos Processuais; II - En Especial: Praxismo, Processualismo e Formalismo no Direito Processual Civil Brasileiro; IV - À Guisa de Conclusões: sobre Leões e Castelos; Referências Bibliográficas
\end{abstract}

\section{INTRODUÇÃO}

O presente ensaio visa a explorar o íntimo e indissociável relacionamento entre o direito e a cultura, voltando-se especificamente ao modo como essa relação opera no âmbito do direito processual civil e, ainda mais especialmente, no espaço de compreensão do direito processual civil luso-brasileiro. Dessarte, impostada a temática, passemos de logo ao seu enfrentamento.

\section{I - Experiência, Cultura e Direito Processual Civil}

É lugar comum no estudo do direito, ganhando horizontes cada vez mais largos dentro do ambiente destinado ao processo civil, afirmar-se que o direito se

\footnotetext{
${ }^{1}$ Professor dos Cursos de Especialização em Processo Civil da Universidade Federal do Rio Grande do Sul, do IPEJUR/CESUSC e da UNISUL/SC; Professor de Direito Processual Civil da Escola Superior da Magistratura Federal do Rio Grande do Sul, da Escola Superior do Ministério Público do Rio Grande do Sul e do Curso de Extensão em Direito Verbo Jurídico; Mestrando em Direito Processual Civil pela Universidade Federal do Rio Grande do Sul; Advogado.
} 
encontra intinamente imbricado com a experiência e a cultura do povo ${ }^{2}$. Nessa senda, refere Castanheira Neves que irreversivelmente "o direito compete à autonomia cultural do homem, que, tanto no seu sentido como no conteúdo da sua normatividade, é uma resposta culturalmente humana (...) ao problema também humano da convivência no mesmo mundo e num certo espaço histórico-social, e assim sem a necessidade ou a indisponibilidade ontológica, mas antes com a historicidade e condicionabilidade de toda a cultura - não é 'descoberto' em termos da objectividade essencial pela 'razão teórica' e no domínio da flosofia especulativa ou teorética, é constituido por exigências humano-sociais particulares explicitadas pela 'razão prática' e imputado à responsabilidade poiética da filosofia prática"'. Vale dizer: a experiência, como dado recollhido da prática contínua e indevassável da vida, e a cultura, "considerada como o conjunto de vivências de ordem espiritual e material, que singularizam determinada época de uma sociedade", na clássica definição de Galeno Lacerda ${ }^{4}$, informam e moldam o direito, fazendo-o, ao fin e ao cabo, espelho seguro e fiel da realidade histórica neste ou naquele sucesso de tempo socialmente considerado.

Essa relação entre direito e cultura sobra ainda mais evidente se procurarmos evidenciá-la a propósito do direito processual civil, "tamo das leis mais rente à vida", consoante anota Pontes de Miranda no prólogo de seus opulentos Comentários ao Código de Processo Civil vigente. Com efeito, tem-se defendido, não sem razão, que "a estrutura mesma do processo civil depende dos valores adotados e, então, não se trata de simples adaptação técnica do instrumento processual a um objetivo determinado, mas especialmente de uma escolha de natureza política, escolha essa

\footnotetext{
${ }^{2}$ Nesse sentido, em termos gerais, Antônio Castanheira Neves, Metodologia Jurídica - Problemas Fundamentais. Coimbra: Coimbra Editora, 1993, p. 47, Migtuel Reale, Lições Preliminares de Direito, 23. ed,. São Paulo: Saraiva, 1996, p. 32; especificamente no que tange ao processo civil, entre outros, Ovídio Araújo Baptista da Silva, Jurisdição e Execução na Tradição RomanoCanônica, 2. cd.. Săo Paulo: Revista dos Tribunais, 1997, pp. 192/219, Galeno Lacerda, "Processo e Cultura". In: Revista de Direito Processual Civil. São Paulo: Saraiva, 1961, p. 74, vol. III; Carlos Alberto Alvaro de Oliveira, Do Pormalismo no Processo Civil, 2. ed.. São Paulo: Saraiva, 2003, pp. 73/76, Daniel Francisco Mitidiero e Hermes Zaneti Júnior, "Entre o Passado e o Futuro: Ủma Breve Introdução às Incertas Dimensóes do Presente em Direito Processual Civil". In: Introdução ao Estudo do Processo Civil - Primeiras Linhas de um Paradigma Emergente. Porto Alegre: Sérgio Antônio Fabris Editor, 2004, p. 11, Vittorio Denti, "Diritto Comparato e Scienza del Processo". In: Rivista di Dirito Processuale. Padova: Cedam, 1979, pp. 335/336, vol. XXXIV; Fritz Baur, "Il Processo e le Correnti Culturali Contemporanee". In: Rivista di Diritio Processuale. Padova: Cedam, 1972, pp. 253/271, vol. XXVII.

${ }^{3}$ Metodologia Juridica

- Problemas Fundamentais. Coimbra: Coimbra Editora, 1993, p. 47.

4 "Processo e Culura". In: Revista de Direito Processual Civil. São Paulo: Saraiva, 1961, p. 75, vol. III.

${ }^{5}$ Pontes de Miranda, Comentários ao Código de Processo Civil, 5. ed.. Rio de Janeiro: Forerse, 1997, p. XYI, prólogo, tomo I.
} 
ligada às formas e ao objetivo da própria administração judicial. (...) Desse modo, a questão axiológica termina por se precipitar no ordenamento de cada sistema e na própria configuração interna do processo, pela indubitável natureza de fenômeno cultural deste e do próprio direito, fazendo com que aí interfira o conjunto de modos de vida criados, apreendidos e transmitidos de geração em geração, entre os membros de uma determinada sociedade". Aliás, muiros são os exemplos que comprovan o inabalável liame que está a jungir o processo civil e a cultura social.

Consoante lembra Vittorio Denti, a propósito da influência de concepções religiosas (e, pois, culturais) na conformação do fenômeno jurídico-processual, o modo de conceber a busca pela "verdade" no processo e particularmente a defesa da privacidade en face dos meios de prova é bastante diferenciado no que toca aos países de inspiração católica e de inspiração protestante: usualmente, a cultura católica tende a ser mais ciosa da tutela de sua intimidade do que a cultufa protestante, limitando-se, assim, a pesquisa probatória àquilo que não desafie a moral cristã ${ }^{7}$. Trabalhando ainda com a influência religiosa na construção do direiro processual civil, assevera Max Weber que a acentuação daquilo que hoje conhecemos como princípio inquisitório (como algo contraposto ao princípio dispositivo ou principio

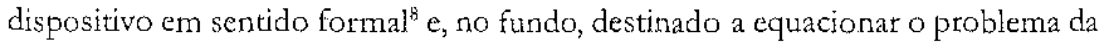
divisão de trabalho entre os sujeitos processuais) em determinados assuntos de direito processual (notadamente no que concerne à possibilidade de instrução probatória de ofício, consagrada em generosa escala no art. 130 do nosso Código de Processo Civil) não fora mais do que a contribuição da justiça teocrática à justiça profana, uma vez que àquela intcressa con aguda intensidade a "averiguação ótima dos fatos verdadeiros", o que de modo nenhum poderia ficar, dessarte, "à mercê do arbítrio das partes". Essa constatação, de resto, talvez explique a boa aceitação, entre nós, da iniciativa probatória oficial, tendo em conta nosso indefectivel legado católicolusitano.

Explorando a mesma relação entre processo e religião, observa Galeno Lacerda que " $\mathrm{é}$ interessante o paralelismo que se verifica entre a fase mais recuada do processo romano, o período das ações da lei, que vigorou desde os primórdios de Roma atéo segundo século antes de Cristo, e o formalismo do processo germânico primitivo, vigente entre os bárbaros e dominante no processo feudal da Idade Média. $\mathrm{O}$

${ }^{6}$ Carlos Alberto Alvaro de Oliveira, Do Formalismo no Processo Civil, 2. ed.. São Paulo: Saraiva, 2003 , p. 74.

" "Diritto Comparato e Scienza del Processo". In: Rivista de Diritto Processuale. Padova: Cedam, 1979 , p. 335, vol. XXXIV.

"Sobre o conceito de principio dispositivo ou princípio dispositivo en sentido formal, com as devidas indicaçóes bibliográficas, consulte-se Daniel Francisco Mitidiero, Comentários ao Código de Processo Civil. São Paulo: Memória Jurídica Editora, 2004, PP. 541/543, tomo I.

'Economia e Sociedade. Brasilia: Editora Universidade de Brasilia, 1999, p. 116, vol. I. 
formalismo do processo romano das legis actiones nos é descrito com abundância de detalhes por Gaio. Bastava que o litigante não reproduzisse com absoluta fidelidade as palavras da lei, ou deixasse de praticar o ato na forma prescrita, para que perdesse a demanda, sem que fizesse qualquer mossa ao espírito do julgador o mérito da lide. Hoje, os romanistas mais eminentes reconhecem no titual simbólico do sacramentum, a mais antiga ação da lei, traços inequivocos da concepção religiosa da época. O mesmo acontece no processo primitivo dos povos germânicos, a refletir-se por largo período da história medieval. O que importa é harmonizar o grupo social, para que esteja sempre pronto aos empreendimentos bélicos do chefe. E isto se logra através das ordálias, ou juizos divinos, pois, com efeito, corresponde à concepção religiosa dominante, não poder a divindade permitir que o infrator, que o criminoso, triunfe no processo. Omite-se, assim, o juizo humano, e o processo se limita a uma prova imposta pela comunidade às partes. O resultado da prova será juizo de Deus. E êste é o que importa. Elimina-se o conflito, para o bem comum. Acata-se a vontade divina. E então os litígios se resolvem pelo duelo, pelas provas da água, do fogo, e tantas outras"10.

Ademais, a própria conformação das características do povo influencia na construção dos institutos jurídico-processuais. Tome-se como exemplo a carga eficacial das ações (de direito marerial) e das sentenças preponderantemente mandamentais. Embora de pré-forma alena ${ }^{11}$, a eficácia mandamental (diria Luiz Guilherme Marinoni, a técnica processual mandamental ${ }^{12}$ ), tal como a concebemos hoje, é produto da ciência jurídica brasileira ${ }^{13}$. Com efeito, nada que melhor se ajuste à mentalidade da

to "Processo e Cuinura". In: Revista de Direito Processual Civil. São Paulo: Saraiva, 1961, p. 78, vol. III.

" $E$ de sabença corrente que Pontes de Miranda se inspirou em Georg Kuttner para construção dogmática da classe das ações e sentenças preponderatntemente mandamentais (conforme Tratados das Açôes. São Paulo: Revista dos Tribunais, 1976, p. 9, tomo VI).

12 Técnica Processual e Tutela dos Direitos. São Paulo: Revista dos Tribunais, 2004, p. 146.

13 Sobre a caracterização da carga eficacial manjamental, consulte-se, entre outros, Pontes de Miranda, Comentários ao Código de Processo Civil, 5. ed.. Rio de Janeiro: Forense, 1997, pp. 204/ 212, tomo I; Tratado das Ações. São Paulo: Revista dos Tribunais, 1970, pp. 117/122, tomo I; Tratado das Ações. São Paulo: Revista dos Tribunais, 1976, pp. 3/12, tomo VI; Ovídio Araúio Baptista da Silva, "Sentença Mandamental". In: Sentença e Coisa Julgada, 4. ed.. Rio de Janeiro: Forense, 2003, pp. 21/69; Curso de Processo Civil, 4. ed.. São Paulo: Revista dos Tribunais, 2000, pp. 335/365, vol. If José Cátos Barbosa Moreita, "A Sentença Mandamental - Da Alemanha ao Brasil". In: Temas de Direito Processual. São Páulo: Saraiva, 2001, pp. 53/70, Sérina Série; Carlos Alberto Alvaro de Oliveira, "O Problema da Effcácia da Sentença". In: Revista Gênesis de Direito Processual Civil. Curitiba: Gênesis, 2003, pp. 437/449, n. 29; Hermes Zaneti Júnior, Mandado de Segurança Coletivo -. Aspectos Processuais Controversos. Porto Alegre: Sérgio Antônio Fabris Editor, 2001, pp. 145/161; Daniel Francisco Miticliero, Comentários ao Código de Processo Civil. São Paulo: Memória Jurídica Editora, 2004, pp. 102/107, tomo I; "Por umá Nova Teoria Geral da Ação: as Orientações Unitárias e a Orientação Dualista da Ação". In: Introdução no Esrudo do Processo Civil - Primeiras Linhas de um Paradigma Emergente. Porto Alegre: Sérgio Antônio Fabris Editor, 2004, pp. 101/108, cm co-autoria com Hermes Zanet Júnior. 
península ibérica, de que recolhemos o legado, "memorável herança, de que sempre havemos de nos envaidecer" ${ }^{\prime \prime 4}$, do que o trato com o imperativo, dado que a vontade de mandar e a disposição para cumprir ordens eram mesno peculiares aos portugueses e espanhói ${ }^{15}$. Isso talvez não só explique a construção da carga eficacial mandamental, mas também o excelente êxito do nosso mandado de segurança.

De resto, tal como sucede acerca dos exemplos já lembrados, manifestações politicas igualmente se projetam no tecido processual. Representando a forma em sentido estrito uma das mais vivas garantias processuais contra o arbítrio estatal, vocacionada primacialmente à salvaguarda dos direitos e da liberdade individua $1^{16}$, natural que Estados despóticos ou totalitários se sintam tentados a aboli-la tanto quanto possível da malha processual, a minar, dessarte, a possivel resistência do cidadão em face de eventuais investidas ilegítimas do poder constituído à sua esfera jurídica ${ }^{17}$. Pense-se, por exemplo, no direito processual civil nazista ou stalinista ${ }^{18}$.

Tudo sopesado, parece-nos indubitável teconhecer ao direito processual civil o seu caráter histórico-cultural. Assentada essa inafastável realidade, cumpre-nos, agora, densificar um pouco mais o nosso discurso, visando a organizar em grandes linhas eventuais tendências em tema de processo civil.

\section{II - Endereços Culturais e Modelos Processuais}

Recolhem-se, na história, alguns endeteços culturais que nos remetem, basicamente, a três modelos processuais: praxismo, processualismo e formalismo ${ }^{19}$. $O$ que se quer significar com cada um desses termos? É o que passamos a expor.

14 Pontes de Miranda, Comentários ao Código de Processo Civil, 5. ed.. Rio de Janeiro: Forense, 1997, p. 4, tomo I.

${ }^{15}$ Neste sentido, por todos, Sérgio Buarque de Holanda, Rázes do Brasil, 26. ed., 17. tiragen. São Paulo: Companhia das Letras, 2003, p. 39.

16. Assim, por todos, Piero Calamandret, "Istitumioni di Diritto Processuale Civile".

In: Opere Giuridiche.

Napoli: Morano Editore, 1970, p. 168, vol. IV. Anote-se, outrossim, que se está a empregar o conceito de forma em sentido estrito querencto representar-se o "invólucro do ato processual, a maneira como deve este se exteriorizar" (Carlos Alberto Alvaro de Oliveira, Do Formalismo no Processo Civil, 2. ed.. São Paulo: Saraiva, 2003, p. 5), isto é, o seu "modo di apparire nella realtà" (Elio Fazzalari, Istituzioni di Diritto Processuale. Padova: Cedam, 1975, p. 157).

17 Assim, ainda aqui, Galeno Lacerda, "Processo e Culura". In: Revista de Direito Processual Civil. São Paulo: Saraiva, 1961, p. 79, vol. III.

${ }^{18}$ Acerca, L. A. Becker, "A Estória do Processo entre a Magia e o Absurdo". In: Elementos para uma Teoria Crítica do Processo. Porto Alegre: Sérgio Antônio Fabris Editor, 2002, pp. 64/65, em co-autoria com E. L. Silva Santos.

19 A expressăo "modelos processuais" quer significar, no âmbito do presente ensaio, a simples similitude entre esta ou aquela atitude ern termos gerais, com elementos de conexão bastante parecidos, sem que tal importe, no entanto, verdadeira identidade entre as tendências recolhidas sob o mesmo rótulo. O sentido que se dá à palavra "modelo", pois, embora se aproxime, não 
O praxismo em direito processual civil congrega todas as manifestações culturais que formam aquilo que Nicola Picardi apontou como sendo a pré-história do processo civil, antes, portanto, do aparecimento da "ciência" processual". Vale dizer: processo como "iudicium" e não'ainda como "processus". Ensartam-se nesse endereço o processo civil romano, em qualquer de seus três períodos (legis actiones, per formulas e cognitio extra ordinemi) ${ }^{21}$, e o processo civil comum (à evidência, aí retratados, en maior ou menor escala, igualmente os seus próprios elementos formativos: o tomano, o canônico e o germânico bárbaró) ${ }^{22}$.

A postura metodológica que informava o praxismo era a sincrética, com o que se oferecia corrente a caracterização do direito processual civil como direito adjetivo, como algo que só ostentava existência se ligado ao dircito substantivo ${ }^{23}$. A respeito, refere Cândido Rangel Dinamarco que no periodo do sincretismo "os conhecimentos eram puramente empíricos, sem qualquer consciência de princípios, sem conceitos próprios e sem a definição de um método. O processo mesmo, como realidade da experiência perante os juízos e tribunais, era visto apenas en sua realidade física exterior e perceptivel aos sentidos: confundiam-no com o mero procedimento quando

coincide integralmente com aquele empregado por Miguel Reale quando conceitua modelos como "estruturas normativas que ordenam fatos segundo valores, numa qualificação cipológica de comportamentos futuros, a que se ligam determinadas conseqüências" ("Para uma Teoria dos Modelos Juridicos". In: Estudos de Filosofáa e de Ciência do Direito. São Paulo: Saraiva, 1978, p. 17).

20 "Processo Civile (Diritto Moderno)". In: Enciclopedia del Diritto. Milano: Giuffrè, 1987, pp. 102/104, vol. XXVI.

${ }^{21}$ Sobre o processo civil romano, consulte-se, entre outros, Carlos Alberto Alvaro de Oliveira, Do Formalismo no Processo Civil, 2. ed.. São Paulo: Saraiva, 2003, pp. 16/24; José Rogério Cru\% e Tucci e Luiz Carlos de Azevedo, Liçöes de História do Processo Civil Romano, 1. ed., 2. tiragenn. São Paulo: Revista dos Tribunais, 2001; Max Kaser, Direito Privado Romano. Lisboa: Fundação Calouste Gulbenkian, 1999, 427/473 e Mário Talamanca, "Processo Civile (Diritto Romano)". In: Eneiclopedia del Diritto. Milano: Giuffrè, 1987, pp. 1/79, vol. XXXVI.

22 Sobre o processo civil comum, consulte-se, entre outros, Carlos Alberto Alvaro de Oliveira, Do Formalismo no Processo Civil, 2. ed.. São Paulo: Saraiva, 2003, pp. 24/33, Francesco Calasso, Medio L̀vo del Diritto. Milano: Giuffè̀, 1954, vol. I e Adriana Campitelli, "Processo Civile (Diritto Intermedio)". In: Enciclopedia del Diritto. Milano: Giuffrè, 1987, pp. 79/101, vol. XXXVI.

23 A respeito, confira-se a clássica crítica de Galeno Lacerca: "erro arraigado, cometido até por autores de tomo, consiste em definir o direito processual como direito adjetivo, ou como direito formal. O primeiro, de impropriedade manifesta, legou-nos Bentham. Tăo intpróprio é definir o arado como adjetivo da terra, o piano como adjetivo da música, quanto o processo como adjetivo do direito em funçẩo do qual ele atua. Instumento nâo constitui qualidade da matéria que modela, mas ente ontologicamente distinto, embora a esta vinculacto por um nexo de finalidade. Se não é qualidade, tambén não será forma, conceito que pressupõe a mesma $\mathrm{c}$, no caso, inexistente integração ontológica com a matéria. A toda evidência, processo não significa forma do direito material. Aqui, o erro provém de indevida aplicação aos dois mamos do diretto das noçoes metafísicas de matéria e forma, como conceito complementares. Definidas as normas fundamentais, reguladoras das relações jurídicas, como dirieto material, 
o definiam como sucessão de atos, sem nada se dizerem sobre a relação jurídica que existe entre seus sujeitos (relação jurídica processual), nem sobre a conveniência política de deixar caminho aberto para a participação dos litigantes (contraditório)"24. A racionalidade que informava ofenôtmeno jurídico de um modo geral eta a racionalidade prática, com a mobilização argumentativa dos sujeitos processuais direcionada à resolução de problemas concretos, à consecução do justo pelo "iudicium". O sentido ético do jurídico, com o seu inexorável apelo a valores (o virtuoso, o bom, o justo), participava de maneira bastante íntima dessa visão de mundo: o direito, enquanto tal, só poderia visar ao justo.

Sucedeu ao praxismo aquilo que ora estamos a designar por processualismo, movimento cultural próprio da Idade Moderna no campo do processo civil. Seu principal intento fora a tecnicização do direito e a despolitização de seus operadores ${ }^{25}$, reduzidos à condição de verdadeiros "escravos do poder", como ben observa Ovídio Araújo Baptista da Silva ${ }^{2 \pi}$, a postular o processo civil como um instrumento puramente técnico, totalmente alheio a valores em sua intencionalidade operacional.

O método de que se servia o processualismo era o científico ou autonomista, através do qual os estudiosos se lançaram à tarefa de expulsar da disciplina processual todo e qualquer resíduo de direito material, forçados que estavam a justificar o direito processual civil como un ramo próprio e autônomo da árvore jurídica ${ }^{27}$. No que toca à racionalidade jurídica, essa se identificava com uma racionalidade teórica, do tipo positivo, apta a retirar do plano da relação jurídica processual o problema da

ao direito disciplinador do processo outra qualificação não restaria senão a de formal. $O$ paralelo se revela primário em seu simplismo sofistico. O direito material há de regular as formas próprias que substanciam e especificam os atos jurídicos materiais, ao passo que o direito processual, como instrumento de definição e tealização daquele em concreto, há de disciplinar, também, as formas que substanciatn e especificam os atos jurídicos processuais. Em suma, a antítese não é direito material - direito formal e sim, direito material - direito instrumental. Isto porque instrumento, como ente a se, possui matéria e formas próprias, independentes da matétia e da forma da realidade jurídica, dita material, sobre a qual opera" (Comentátios ao Código de Processo Civil, 7. eả. Rio de Janeiro; Forense, 1998, pp. 23/24, vol. VIII, tomo I).

${ }^{24}$ Instituições de Direito Processual Civil, 3. ed.. São Paulo: Malheiros, 2003, p. 255, vol. I; A Instrumentalidade do Processo, 8. ed.. São Paulo: Malheiros, 2000, pP. 17/18; Fundamentos do Processo Civil Moderno, 4. ed.. São Paulo: Malheiros, 2001, pp. 727/278, tomo II.

${ }^{25}$ Assim, por todos, Giovanni Tarello, Storia della Cultura Giuridica Moderna. Bologna: II Mulino, 1976, p. 16.

${ }^{26}$ Jurisdição e Execuçäo na Tradição Romano-Canônica, 2. ed.. São Paulo: Revista dos Tribunais, 1997, p. 219.

${ }^{27}$ Neste sentido, por todos, Cändido Rangel Dinamarco, Instituiçóes de Direito Processual Civil, 3. ed.. São Paulo: Malheiros, 2003, pp. 255/257, vol. I; A Instrumentalidade do Processo, 8. ed.. São Paulo: Malheiros, 2000, pp. 18/21; Fundamentos do Processo Civil Moderno, 4. ed.. São Paulo: Malheiros, 2001 , pp. $728 / 729$, tomo 11 . 
justiça, colocando em seu lugar o problema da norma jurídica (identificada essa com aquilo que provém do Estado, mais especificamente do Poder Legislativo, de maneira vertical, autoritativa). O direito, então, tendia à norma estatal, passível de uma única interpretação "verdadeira" (a tarefa do juiz, então, cinģia-se a descobrir a "vontade concreta da lei", na célebre expressão de Giuseppe Chiovenda ${ }^{28}$ ), assumindo foros de clareza, certeza e previsibilidade (projeto iluminista-racionalista para ciência juridica ${ }^{29}$, destrinchado principalmente pelas codificações oitocentistas, na precisa opinião de Giovanni Tarello $0^{3 \%}$. Nesse quadrante, o processo civil acabou relegado a um expediente de índole técnica, de todo infenso a valores em seu trato cotidiano.

Deságua-se, de postremeiro, no formalismo processual, entendido esse como movimento cultural destinado a concretizar valores constitucionais no tecido processual (no formalismo ou na forma em sentido amplo, no exato sentido que dá à expressão Carlos Alberto Alvaro de Oliveira ${ }^{35}$ ) à força do caráter nitidamente instrumental da relação jurídica processual cm contraditório ${ }^{32}$, trazendo novamente ao plano dos operadores do processo a busca pelo justo. $O$ método é o instrumental ${ }^{33}$ e a racionalidade que perpassa o fenômeno é a racionalidade prática (quer na sua vertente processual, tópica-retótica, quer na sua vertente material $)^{34}$, resgatando-se,

${ }^{28}$ Assim, Instituições de Direito Processual Civil, 3, ed., Săo Paulo: Saraiva, 1969, p. 40, vol. 1.

${ }^{29}$ Assim, entre outros, Karl Engisch, Introdução ao Pensamento Jurídico, 8. ed.. Lisboa: Fundação Calouste Gubenkian, 2001, p. 206.

30 Storia della Cultura Giuridica Moderna. Bologna: I Mulino, 1976, p. 18.

${ }^{31}$ Segundo Carlos Alberto Alvaro de Oliveira, o formalismo ou forma em sentido amplo abrange "a totalidade formal do processo, compreendendo não só a forma, ou as formalidades, mas especialmente a delimitação dos poderes, faculdades e deveres dos sujeitos processuais, coordenação de sua atividade, ordenação do procedimento e organização do processo, com vistas a que sejam atingidas suas finalidades primordiais", investindo-se, assim, na "tarefa de indicar as fronteiras para o começo e o fim do processo, circunscrever o material a ser formado, estabejecer dentro de quais limites devem cooperar e agir as pessoas atuantes no processo para o seu desenvolvimento", com o que "contém, portanto, a própria idéia do processo como organização da desordem, emprestando previsibilidade a todo o procedimento" (Do Formalismo no Processo Civil, 2. ed.. São Paulo: Saraiva, 2003, pp. 6/7).

32 Sobre a caracterização do processo como uma relaçăo jurídica processual em contraditório, consulte-se Cândido Rangel Dinamarco, Instituições de Direito Processual Civil, 3. ed.. São Paulo: Malheiros, 2003, p. 299, vol. I; A Instrumentalidade do Processo, 8. ed.. São Paulo: Malheiros, 2000, p. 135; Fundamentos do Processo Civil Moderno, 4. ed.. São Paulo: Malheiros, 2001, p. 76, nota de rodapé n. 9, tomo I; Luiz Guílherne Marinoni, Novas Linhas do Processo Civil, 4. ed.. São Paulo: Malheiros, 2000, pp. 251/252; Daniel Francisco Micudero, Comentários ao Código de Processo Civil. São Paulo: Memória Jurídica Editora, 2004, pp. 16/20, tomo 1.

${ }^{33}$ Assim, Cândido Rangel Dinamarco, Instituiçōes de Direito Processual Civil, 3. ed.. São Paulo: Malheiros, 2003, p. 257, vol. I; A Instrumentalidade do Processo, 8. ed. Säo Paulo: Malheiros, 2000, pp. 21/24; Fundamentos do Processo Civil Moderno, 4. ed.. São Paulo: Malheiros, 2001, Pp. 729/730, tomo 11 .

${ }^{34}$ Sobre a racionalidade prática e as suas duas vertentes, consulte-se, por todos, Antônio Castanheira Neves, Metodologia Juridica - Problemas Fundamentais. Coimbra: Coimbra Editota, 1993, pp. 71/81. 
en um outro nível qualitativo, o pensamento problemático para o direito processual civil. O processo deixa de ser visto como mera técnica, tal como tínhamos a propósito do direito moderno, assumindo a estatura de um verdadeiro instrumento ético, sem que se deixe de reconhecer, no entanto, a sua estruturação igualmente técnica ${ }^{35}$. Tal é o momento que ora se está a viver: formalismo processual, en que a valores constitucionais impregnam a técnica do processo, escrevendo mesmo, como bem observa Vittorio Denti, um novo "capitolo di storia della nostra cultura giuridica" 36 .

Lecionando a respeito, bem refere Cândido Rangel Dinamarco que "visto por essa perspectiva integrada, o processo deixa de ser considerado mero instrumento técnico para a realização do direito material. Dizia-se que a missão do juiz seria a efetivação das leis substanciais, não lhe competindo o juizo do bem ou do mal, do justo ou do injusto. Sentenças injustas serian o fruto de leis injustas e a responsabilidade por essa injustiça seria do legislador, não do juiz. Mas o jưzz moderno tem solene compromisso com a justiça. Não só deve participar adequadamente das atividades processuais, endereçando-as à descoberta de fatos relevantes e à correta interpretação da lei, como ainda (e principalmente) buscando oferecer às partes a solução que realmente realize o escopo de fazer justiça. Eis porque a doutrina atual considera pobre e insuficiente a indicação do processo como mera técnica instrumentalmente conexa ao direito material. Ele é una técnica, sim, mas técnica que deve ser informada pelos objetivos e ideologias revelados na ciência processual e levada a efeito com vista à efetivação do valor do justo. Conjuntamente com o próprio direito substancial, o processo é instrumentalmente conexo ao supremo objetivo de pacificar com justiçą37.

Praxismo, processualismo e formalismo: cá estão os nossos três modelos processuais, sinalizados por três endereços culturais (pré-história processual, modernidade processual e contemporaneidade processual). Diante dos mesmos, desenhados en abstrato c sem maiores amarras com esse ou aquele ordenamento em particular, vejamos por onde se acomoda a tradição luso-brasileira.

\section{III - Em Especial: Praxismo, Processualismo e Formalismo no Direito Processual Civil Brasileiro}

O direito processual civil brasileiro, como o direito pátrio em geral, não pode ser estudado "desde as sementes", porque "nasceu do galho de planta, que o

\footnotetext{
3. Assim, por todos, Cândido Rangel Dinamarco, Instituições de Direito Processual Civil, 3. ed.. São Paulo: Maheiros, 2003, pp. 60/62, vol. I.

36 "Valori Costituzionall e Cultura Processuale". In: Rivista di Diritto Processuale. Padova: Cedam, 1984, p. 443, vol. XXXXX.

${ }^{37}$ Instituições de Direito Processual Civil, 3. ed.. São Paulo: Malheiros, 2003, pp. 60/61, vol. 1 .
} 
colonizador português - gente de rija têmpera, no ativo século XVI e naquele cansado século XVII em que se completa o descobrimento da América - trouxe e enxertou no novo continente" 38 . Uma volta às sementes, pois, afigura-se de todo recomendável para análise mais precisa do nosso processo civil, da maneira como aquelas tendências processuais de que há pouco falávamos se manifestaram entre nós.

No que ora nos interessa, porque integrantes de nossa mais funda tradição, parece-nos fecundo separar o antigo direito processual civil lusitano em dois períodos distintos: periodo de individualização do direito português (também conhecido como períado de direito costumeiro ou foraleiro) e período de inspiração romanocanônica (subdivido em dois: período da recepção do direito romano em Portugal e período das Ordenaçóes) ${ }^{39}$. Vejamos um pouco mais de perto cada uma dessas fases do direito português e de como o processo civil então ganhava corpo na prática jurídica.

O periodo de direito consuctudinário e foraleiro, dito por Mário Júlio de Almeida Costa "período de individualização do direito português" "4h, vai do século XII ao século XIII, especificamente do ano em que Afonso Henriques passa a intitular-se rei (e, pois, da fundação da nacionalidade portuguesa, 1140) até o início do reinado de Afonso III (1248). O sistema jurídico vai principalmente dominado pelo costume (notadamente de origem germânica, sem que se possa, no entanto, descartar a confluência de outras fontes, como a muçulmana e a francesa) e pelos forais, fato advindo da necessidade de criação espontânea do direito, porquanto o Estado, nesta altura, mais interessado estava no intento da Reconquista do que na organização do seu próprio cotidiano jurídico e no de seus súditos ${ }^{41}$.

No que concerne aos costumes, sustenta-se normalmente a sua origem germânica (ainda que de certo modo já "romanizados", uma vez que os visigodos, no quando da ocupação da península ibérica, já haviam sentido em dada medida a poderosa influência romana ${ }^{4}$ ), mas não se pode recusar, de outro lado, a confluência

${ }^{38}$ Pontes de Miranda, Fontes e Evoluçāo do Direito Civil Brasileiro, 2. ed.. Rio de Janeiro: Forense, 1981, p. 27.

39 Acerca da terminologia empregada, consulte-se Mário Júlio de Almeida Costa, História do Direito Português, 2. ed.. Coimbra: Almedina, 1992, pp. 174/175; Nuno J. Espinosa Gomes da Silva, História do Direito Porruguês. Lisboa: Fundação Calouste Gulbenkian, 1985, pp. 99, 129 e 185 , vol. I.

40 Histónia do Direito Português, 2. ed.. Coimbra: Almedina, 1992, p. 174.

${ }^{41}$ Consoante observa Nuno J. Espinosa Gomes da Silva, História do Direito Português. Lisboa: Fundação Calouste Gulbenkian, 1985, p. 106, vol. l.

${ }^{42}$ Assim, Nuno J. Espinosa Gomes da Silva, História do Direito Português. Lisboa: Fundação Calouste Gulbenkian, 1985, pp. 40/41, vol. I; Marcello Caetano, História do Direito Português (1140-1495), 2. ed.. Lisboa: Editorial Verbo, 1985, p. 92. 
de elementos muçulmanos (senão de maneira mais sensivel na confotmação do diteito proptiamente dita, tendo em conta a difícil barreira representada pela mentalidade cristã então vicejante, principalmente na construção do vocabulário técnicojurídico), franceses (como a posse de ano e dia e sua proteção processual via "ações de força", consoante observa Ovidio Araújo Baptista da Silva ${ }^{43}$, tidas pelos velhos juristas portugueses como ações com mandatum de manutenendo, em que a força mandamental despontava nítida ${ }^{44}$ ) e, ainda, a influência de fatores próprios do momento do Estado de Reconquista, que assim não se filiam nem a essa nem aquela expetiência anterior (como a instituição do "concelho", em que os homens se reuniam, longe da autoridade régia, para discussâo de interesses comuns ${ }^{45}$. Cumpre lembrar, de resto, que a própria expressão "direito consuetudinário" àquele tempo tinha uma abrangência muito mais generosa que aquela hoje ostentada: com efeito, enquanto hodiernamente se identifica o costume com a prática constante e reiterada de dada conduta que se acredita boa e obrigatória, no quando do periodo de individualização do direito português tomava-se por costume toda manifestação normativa despida de caráter legisiativo, enriquecendo-se, destarte, a sua abrangência semântica e, pois, a sua densidade jurídica ${ }^{46}$.

Quanto ao direito foraleiro, destaca-se o Código Visigótico, também conhecido como "lex gothorum", "forum judicum" ou "liber indicialis", tido por Marcello Caetano como um "dos mais notáveis monumentos juridicos da Idade Média" nele refletindo-se basicamente compromissos romanos, eclesiásticos e germânicos antigos". Referido foral compunha-se de un primeiro título ("De la eleccion de los príncipes et del insinnamien to como deben iudgar derecho et de la pena de aquellos que iudgan torto"), no qual se continham doze livtos (Libro I, "Del facedor de la ley et de las leyes", Libro II, "De los juicios y causas", Libro III, "De los casamientos é de las nascencias", Libro IV, "Del linage natural", Libro V, "De las avenencias é de las compras", Libro VI, "De los malfechos é de las penas é de los tomentos", Libro VII, "De los furtos é de los engannos", Libro VIII, "De las fuerzas é de los dammos é de los quebrantanientos", Libro IX, "De los siervos foidos é de los que se tornan", Libro X, "De las particiones é de los tiempos é de los annos é de las lindes", Libro XI,

${ }^{43}$ Procedimentos Especiais - Exegese do Código de Processo Civil (arts. 890 a 981). Rio de Janeiro: Aide Editora, 1993, p. 226.

${ }_{44}$ Pontes de Miranda, Comentários ao Código de Processo Civil, 2. ed. Rio de Janeiro: Forense, 2004, p. 185, tomo XIII.

${ }^{45}$ Assim, Nuno J. Espinosa Gomes da Silva, História do Direito Português. Lisboa: Fundação Calouste Gubenkian, 1985, Pp. 109/111, vol. I.

${ }^{46}$ Neste sentido, Mário Júlo de Almeida Costa, História do Direito Português, 2. ed.. Coimbra: Almedina, 1992, pp. 190/191.

${ }^{47}$ História do Direito Português (1140-1495), 2. ed.. Lisboa: Editorial Verbo, 1985, p. 106.

${ }^{48}$ Assim, Marcello Caetano, História do Direito Português (1140-1495), 2. ed.. Lisboa: Editorial Verbo, 1985, p. 106. 
"De los fisicos é de los mercadores de ultramar é de los marineros" e Libro XII, "De devedar los tuertos é derraigar las sectas é sus dichos").

Outras fontes, de postremeiro, tiveram lugar no período que ora estamos a tratar: pense-se, por exemplo, no papel desempenhado pelas Cartas de Privilégio, nas Leis da Cúria de Leão e dos Concílios de Coiança e Oviedo e nas Concórdias, todas, porém, com importância menos marcada na caracterização do sistema jurídico da época. A doutrina é algo tranqüila a respeito ${ }^{49}$.

Quanto ao processo civil, esse se encontrava basicamente regido pelo "form juticum" que, em seu segundo livro ("de los juicios y causas"), cuidava das cousas relativas ao direito judiciário. Virha dividido en cinco títulos: "de los jueces, y de lo que iudgan", "de los compezamientos de los pleytos", "de los mandadores y de las cosas que mandam", "de las testimonias y de lo que testimoniam" e "de los escriptos que deben valer ó nón, é de las mandas de los muertos", cada qual com inúmeras subdivisões internas (o primeiro deles, e talvez o mais interessante, por exemplo, tinha trinta e una subdivisões: "en quanto tiempo deven valer las lcys que son emendadas", "que el rey é los pueblos devem seer sometidos de las leys", que tod omne deve saber las leys", "que las cosas del príncipe deven seer ante ordenadas, é las del pueblo depues", "de toller la cobdicia de los príncipes, é cueno deven seer fechos por escriptos en su nombre de los príncipes", "de los que son rebelles, ó mal obedientes contral príncipe, ó contral pueblo, ó contra la tierra", "que ningúm omne non deve blasphemar el príncipe, nil maldezir", "de toller las leys de los omnes estannos", "que ningum omne non aya otro libro si non este que es fecho d'nuevo", "de los dias, é de las fiestas que non deven tener pleytos", "que los iuezes non oyan ningum pleyto, si no aquel que contenudo es en las leys", "que los pleytos pues que una vez fueren acabados, que non sean depues reboltos", "que ningun onne non deve seer iuez si no al qui lo mandare el príncipe, ó aquel que fuere de consentimiento de las partes, ó demandado de los otros iuezes", "quales pleytos deven iudgar, é á quales personas los deven dar à iudgar", "que los iuezes deven iudgar los pleytos criminales, é los ottos", "de la pena que deven aver aquellos que iudgan, é non an poder de iudgar", "de los que son lamados por letras del iuez, ó por seyello, é non quisieren venir", "del luez que non quier oyr à aquel quel demanda quel faga derecho, ó quel iudga tuerto por enganno, ó por non saber", "del iuez que iudga tuerto por ruego, ó por ignorancia", "del iuez que faz perder alguna cosa por arte, ó por enganno á alguna de las partes", "del iuez que bien quiere entender el pleyto, que deve primeramientre afazer", "del iuez que a sospechosa alguna de las partes", "del iuez cuemo deve iudgar", "del pro, é del danno que deve aver el sayon", "que tod omne

49 Por todos, Mário Júlio de Almeida Costa, História do Direito Português, 2. ed.. Coimbra: Amedina, 1992, pp. 186/194. 
à quien es dado poder de iudgar aya nombre iuez", "que tod atamiento que fuere fecho por fuerza del alcalde depues iuyzio non derecho, non vala", "que el iuyzio, que es dado por mandado del rey, ó por miedo, si es torticero, non vala", "del poder que an los obispos sobre los iuezes, que iudgan tuerto", "que el iuez deve dar razon de quantol demandaren", "de la pena que deve aver el iuez, que toma las cosas aienas, ó las manda tomar" e "de los que non quieren venir por mandado del rey"). O dever de julgar ficava a cargo dos homens do povo, regulatmente investidos na função de juiz, sendo que os feitos raramente terminavam por sentença de mérito, com um juízo de valor sobre o pedido do demandante, mas antes por desistência de alguma das partes ou por transação de ambas, dado altamente demonstrativo d'uma autentica crise na cultura jurídica da época ${ }^{50}$.

Consoante já se frisou, o periodo de influência do direito comum em Portugal pode ser agrupado em dois grandes grupos: o primeiro marca a recepção do direito romano renascido em terras lusas, ao passo que o segundo dá conta especificamente da estratificação do direito comum nas Ordenações portuguesas. Em termos cronológicos, os séculos XIII a XVIII oferecem-se como berço e palco desta inspiração, tocando o lapso temporal que se alonga dos anos de 1248 a 1447 àquele primeiro grupo, sobrando aos anos de 1446 a 1750 a amarração do segundo.

No tocante à recepção do direito romano em Portugal, temos de assentar logo de início que se está a aludir à "recepção do direito romano renascido" e não, simplesmente, à "tecepção do direito romano", locução que, sem a devida complementação, poderia conduzir à falsa idéia de que este direito até então poderia ter sido completamente ignorado pela experiência cultural da Alta Idade Média. Em realidade, sendo a Igreja a única instituição de vulto que sobreviveu à derrocada da Antigüidade, fazendo o elo entre o romano e o bárbaro, e sendo o direito romano a sua lex approbata (lex saeculh), pertinente aos seus negócios tertenos, sobra certo que a influência e a prática deste ordenamento nunca desapareceu, consoante bem observam Paul Koschaker ${ }^{5 t}$ e Nuno J. Espinosa Gomes da Silva ${ }^{52}$. Nesta mesma vertente, escrevendo igualmente sobre o "tenascimento do direito romano", teve a oportunidade de registrar Mário Júlio de Almeida Costa que aquela designação não se mostra "inteiramente pacífica. Na verdade, a palavra 'renascimento' inculca a idéla de que o direito romano justinianeu tenha deixado, em absoluto, de ser conhecido, estudado e aplicado. Ora, isso jamais se verificou. No Oriente, as fontes justinianeias permaneceram até à queda de Constantinopla (1453). Claro que não pode pensar-se numa aplicação completa e inalterada ao longo de tantos séculos. Após a morte de

\footnotetext{
${ }^{51)}$ Conforme anota Nuno J. Espinosa Gomes da Silva, História do Direito Português. Lisboa: Fundação Calouste Gulbenkian, 1985, p. 111, vol. 1.

sl Europa y el Derecho Romano. Madrid: Editorial Revista de Derecho Privado, 1955, p. 103.

${ }^{52}$ História do Direito Português. Lisboa: Fundação Calouste Gulbenkian, 1985, pp. 141/142, vol. I.
} 
Justiniano, a sua obra legislativa tomou-se largamente objecto de paráfrases, traduções para grego, resumos, etc. E essa literatura deu ensejo a que se introduzissem modificaçôes substanciais. A vigência das colectâneas justinianeias, no Ocidente, foi, sem dúvida, algo efêmera. Liga-se, bem dizer, à ltália, mercê do domínio bizantino e de uma promulgação expressa, pelos meados do século VI (a 'pragmatica sanctio' de 554), cuja eficácia persistiria cerca de catorze anos. Seguiu-se a conquista dos Lombardos (568), que não abrangeu todo o território transalpino, embora quebrasse a sua unidade política e circunscrevesse o direito justinianeu a determinadas cidades, como Roma e Ravena, que conservaram relativa autonomia. Também sabemos que as tropas bizantinas ocuparam o Sul da Peninsula Ibérica. Não terá sido, contudo, uma presença susceptível de conduzir a grandes influências juridicas. De qualquer modo, as colectâneas justinianeias chegaram ao mundo ocidental, ainda nessa época. Uma vez conhecidas, continuaram, mais ou menos, a ser conservadas e até analisadas, designadamente nos centros de cultura eclesiástica. Mas isto não significa que, durante os primeiros séculos medievos, tenham conseguido divulgação notória ou alcance efectivo. Pelo contrário, os textos justinianeus, de um modo geral, perderam-se ou cairam no esquecimento. Ora, é para assinalar o contraste entre essa difusão muito modesta ou indiferença e o interesse decisivo que o seu estudo, já com antecedentes no século XI, assume no século XII em diante que se explica e mesmo se justifica a qualificação de renascimento do direito romano"s.3. Q Quando se alude, pois, à "recepção do direito romano" quer-se apontar precisamente o fenômeno da "recepção do direito romano renascido". Vale dizer: quer-se reportar ao reencontro do direito romano através do estudo das fontes justinianas genuínas, à risca de um estudo independente e autônomo da idéia jurídica romana. Até o seu renascimento, o direito romano vinha estudado pelos juristas medievais dissolvido nas artes liberates, constituidas, por exemplo, pelo trivium da gramática, da lógica (dialética) e da retórica, sem que houvesse, salvo no oriente bizantino, escolas de formação especificamente jurídicas ${ }^{54}$. É, pois, com a Escola de Bolonha, Irnério à frente (primus illuminator scientiae nostrae, dito ainda lucema juris), e o método da glosa e, posteriormente, dos comentátios, que o panorama se modificou sensivelmente ${ }^{55}$. Aliás, há quem

${ }_{53}$ História do Direito Português, 2. ed.. Coimbra: Almedina, 1992, pp. 206/207.

${ }^{54}$ Assim, Franz Wieacker, História do Direito Privado Moderno, 2. ed.. Lisboa: Fundação Calouste Gulbenkian, 1993, p. 19.

55 A glosa consistia em mera explicaçâa gramatical, de caráter tão-somente exegético, de palavras ou frases suscetiveis de mais de uma interpretaçăo. O expoente desta vertente é Acúrsio, autor da célebre obra Magna Glosa, escrita provavelmente entre 1220 e 1234. Nos comentários, de outro lado, os autores já possuem uma preocupação em construir um sistema lógico entre as proposições juridicas, apto a superar eventuais e aparentes contradições. O primeiro jurista desta escola é Cino de Pistoia (1270-1336), mas certamente o mais afamado é Bártolo (1313. 1353), seguido de Baldo (1327-1400), tudo conforme Nuno J. Espinosa Gomes da Silva, História do Direito Português. Lisboa: Fundação Calouste Gulbenkian, 1985, pp. 142/145, vol. I. Sobre o método da glosa e dos comentários, ainda, Paul Koschaker, Europa y el Derecho Romano. Madrid: Editorial Revista de Derecho Privado, 1955, pp. 143/145. 
sustente mesmo que o Corpus Itris Civilis tenha sido recepcionado na Europa e, notadamente, na Alemanha, apenas formalmente, uma vez que, materialmente, o direito romano recepcionado teria sido o direito romano já tocado pelos glosadores e comentaristas, ávidos por colocá-lo em hora com as necessidades do dia ${ }^{56} .0$ mesmo se afirma, a propósito, do direito recebido em Portugal, a ponto de se asseverar firmemente que "o romanistno português foi inteiramente, ou quase inteiramente - enquanto na verdade significativo - de cunho escolástico ou bartolista" ${ }^{157}$.

Resta-nos, agora, saber "por que" o direito romano renasceu en Portugal e "como" precisamente se deu esta recepção.

Por que renasceu o direito romano em Portugal? Em breve escorço, pode-se afirmar que a recepção do direito romano em Portugal teve um intento bastante específico: transformar o rei em imperador. Vale dizer: seu desiderato específico fora o de ampliar o espectro de atuação política real, no que, inclusive, a Igreja Católica exerceu um papel sobremaneira destacado ${ }^{5 \%}$. Uma das consequiências de maior vulto desta anchura política mais dilargada do rei está en que esse passa a legislar, apropriando-se do papel de criador do direito (aqui, aliás, o início de nosso "centralismo jurídico"sy).

Como, de outro lado, ocorreu a recepção do direito romano em Portugal? Nuno J. Espinosa Gomes da Silva tessalta a influência de obras doutrinárias e legais castelhanas, escritas em idioma de mais fácil acesso que o latim, com soluções justinianas indicadas de maneira resumida ${ }^{60}$. Dentre as primeiras, Flores de Derecho (também conhecida como Flores de las Leyes), Doctrinal de las Pleytos a Nuevos Tiempos del Juicio, todas de Jácome Ruiz (Mestre Jacob das Leis), todas versando preponderantemente o direito processual civil (melhor, o direito judiciário civil, tendo em conta que, àquele tempo, ainda não haviamos feito a passagem do iudicium ao processus, como bem assinalam Nicola Picardi ${ }^{61}$ e Flermes Zaneti Júnior $\left.{ }^{62}\right)$. Dentre

\footnotetext{
56 Assim, Paul Koschaker, Europa y el Derecho Romano. Madrid: Editorial Revista de Derecho Privado, 1955 , p. 240.

57 Mário Júlio de Ameida Costa, "Fundamentos Históticos do Direito Brasileiro". In: Esstudos de Direito Civil Brasileiro e Português (I Jornada Luso-Brasileira de Direito Civil). São Paulo: Revista dos Tribunais, 1980, p. 111.

${ }^{58}$ Nuno J. Espinosa Gomes da Silva, Fistória do Direito Português. Lisboa: Fundaçäo Calouste Gulbenkian, 1985, pp. 153/157, vol. I.

59 Acerca, Judith Maruins-Costa, A Boâ-Fé no Direito Privado, 1. ed., 2. tragem. São Paulo: Revista dos Tribunais, 2000, pp. 238/241.

6* História do Dircito Português. Lisboa: Fundação Calouste Gubenkian, 1985, p. 159, vol. 1 .

61 "Processo Civile (Diritto Moderno)". In: Enciclopedia del Diritto. Milano: Giuffrè, 1987, pp. $101 / 117$, vol. XXXVI.

62 "O Problema da Verdade no Processo Civil: Modelos de Prova e de Procedimento Probatório". In: Introdução ao Estudo do Processo Civil - Primeiras Linhas de un Paradigma Emergente.
} 
as segundas, cumpre assinalar o Fuero Real, composto entre 1252 e 1255, e Las Siete Partidar, obra que, em Castela, começa ostentando caráter legislativo, passa a uma feição doutrinária e finalmente, em 1348, adquire o valor de direito subsidiário. Referido diplona fora vertido para o português ainda no século XIII, tendo influenciado inequivocamente a redação das Ordenações Afonsinas. Marcello Caetano ${ }^{63}$, ainda, aponta a influência das classes cultas, letrada, na difusão do direito romano em Portugal, sendo que Mário Júlio de Almeida Costa acrescenta à lista de Gomes da Silva e Marcello Caetano a presença de jurisconsultos estrangeiros na Península Ibérica, o maior acesso ao Corpus Iurir Civilis e à glosa respectiva e o ensino do direiro romano, de modo autônomo, nas Universidades ${ }^{64}$.

De resto, no periodo de recepção do direito romano vigiam em Portugal, ainda, outras fontes juridicas: quanto aos assuntos temporais, que ora nos interessan mais de perto, ainda se oferecia grande a influência do costume e, no âmbito local, os forais continuavam a ser a principal fonte de diretto. Algumas leis gerais, porém, começavam a pulular aqui e ali, como concreta expressão da apropriação do direito pelo soberano ${ }^{65}$.

Como vinha disciplinado o processo civil nesse período? A Terceira Partida cuidava do assunto (consoante lá gravado, "tercera partida" é a "que fabla de la Iufticia, e como fe ha de fazer ordenadamente en cada logar, por palabra de Iuyzio, e por obra de fecho, para defembargar: los pleytos') em trinta e dois títulos, cada qual devidanente subdividido em "Ieys", representando, essencialmente, uma tábua de soluções processuais romanas. A matéria apresentava-se da seguinte maneira (ora se reproduz a ordem dos títulos): "de la jufticia", "del demandador, e de las cofas que ha de catar ante que ponga la demanda", "de los demandados, e de las cofas que deven demandar", "de los juezes, e de las cofas que deven fazer guardar", "de los perfoneros", "de los abogados", "de los emplazamientos", "de los affentamientos", "quando deven meter la cofa que contienden en mano del fiel", "como fe deven començar los pleytos por demanda, e por refpuefta", "de las juras que las partes fazen en los pleytos, defpues que fon començados por demanda, e por refpuefta", "de las preguntas que los juezes pueden fazer a las partes en juyzio, defpues que el pleyto es començado por demanda, e por tefpuefta, a que llaman en latin, pofitiones", "de las conofcencias, e de las refpuestas que fazen las partes en juyzio a las demandas, e a las preguntas que fon fechas en razon dellas", "de las pruevas, e de las fofpechas que los

Porto Alegre: Sérgio Antônio Fabris Editor, 2004, pp. 115/164, em co-autoria com Daniel Francisco Mitidiero.

${ }^{63}$ História do Direito Português (1140-1495), 2. ed. Lisboa: Editorial Verbo, 1985, p. 340.

${ }_{64}$ História do Direito Português, 2. ed.. Coimbra: Almedina, 1992, pp. 225/231.

os Assim, Nuno J. Espinosa Gomes da Silva, História do Direito Português. Lisboa: Fundação Calouste Gulbenkian, 1985, pp. 165/167, vol. 1. 
omne aduzen en juyzio fobre las cofas negadas, e dubdofas", "de los plazos que deven dar los judgadores a las partes en juyzio, para provar fus intenciones", "de los teftigos", "de los pefqueridores que han poderio de recebir pruevas por fi de fu officio, maguer las partes no fe las aduxeffen delante", "de las efcrituras porque fe pruevan los pleytos" "de los efcrivanos, e quãtas maneras fon dellos, e que pro nafce de fu officio quando lo fazen lealmente", "de los fellos, e de los felladores de la cancellaria", "de los confejeros", "de los juyzios que dan fin, e acabamiento a los pleytos", "de las alçadas que fazen las partes quando fe tienen por agraviadas de los juyzios que dan contra ellas", "como los juyzios fe pueden tevocar, e oyr de cabo, quando el Rey quifiere fazer merced a alguna de las partes, maguer non fe ouiffe alçado dellos", "de como fe pueden quebrantar los juyzios que fueffen dados contra los menores de veynte, e cinco años, o fus guardadores, maguer non fuc effe tomada alçada", como fe puede defatar el juyzio que es dado por falfas cartas, o por falfas pruevas contra ley", "como los juyzios q fon valederos deven fer cumpridos, e quien los puede cumplir", "de las cofas en que ome puede auer feñono, e como lo puede ganar", "de los tiepos porque ome pierde las fus cofas, e como lo puede ganar", de los tiepos porque ome pierde las fus cofas, tambien muebles como rayzes", "en quãtas maneras puede ome ganar poffefsion, tenencia de las cofas", "de las ferundumbres q han unas cofas en otras, e como fe pueden poner", "de las lavores nuevas como fe puede embargar que fe non fagan, e de las viejas que fe quieren fazer como fe han de fazer". A influência romana era patente, tanto que se observava com bastante agudeza o princípio dispositivo en sentido material (também conhecido como princípio da demanda, Título Il), a garantia do contraditótio (representada pela conformação do juizo como um ato de três pessoas, Títulos II, III, IV e X) e a imparcialidade jurisdicional (Título III), princípios mesmo fundamentais da experiência tomana, segundo observa Max Kaser ${ }^{660}$.

Seguindo-se no tempo, chega-se à época das Ordenaçôes, a qual reptesenta, antes de tudo, um esforço de sistematização das fontes de direito então vigentes em Portugal, a fim de que se tornasse melhor idennificável o direiro incidente e aplicável ao trato cotidiano da vida. Três Ordenaçôes: Afonsinas (1446), Manuelinas (1521) e Filipinas (1603).

Em termos estruturais, as Ordenações Afonsinas foram repartidas em cinco livros, sendo que esses ainda se dividiam em títulos e esses, de seu turno, em parágrafos, sempre precedidos de um proêtrio. A forma quinária, aliás, traz à lembrança a organização das dectetais de Gregório IX, consoante observa Pontes de Miranda ${ }^{67}$. Quanto à matéria tratada em cada um dos livros, lembra Nuno J. Espinosa Gomes

${ }^{66}$ Direito Privado Romano. Lisboa: Fundação Calouste Gulbenkian, 1999, p. 428.

${ }^{64}$ Fontes e Evolução do Direito Civil Brasileiro, 2. ed., Rio de Janeiro: Forense, 1981, p. 39. 
da Silva que "o Livro I, que compreende 72 títulos, contém tegimentos dos cargos públicos, quer régios, quer municipais. O Ljvro II, dividido em 123 títulos, contempla a matéria respeitante à Igreja e à situação dos clérigos, direitos do rei, em geral, e administtação fiscal, jurisdição dos donatários, privilégios da nobreza, e legislação especial de judeus e mouros. O Livro III, abrangendo 128 títulos, ocupa-se do processo civil. O Livro IV, nos seus 112 títulos, trata do direito civil; enfim, o Livro $\mathrm{V}$, com 121 títulos, versa direito e processo penal" ${ }^{\text {"68 }}$.

"Substancialmente", consoante refere ainda Nuno J. Espinosa Gomes da Silva", "as Ordenações Afonsinas constituem uma compilação, actualizada e sistematizada, das várias fontes de direito que tinham aplicação em Portugal. Assim, e grande parte, são elas formadas por leis anteriores, respostas a capítulos apresentados em Cortes, concórdias e concordatas, costumes, normas das Siete Partidas e disposições dos direitos romano e canônico". Do ponto de vista estritamente juridico, pois, as Ordenações Afonsinas não chegaram a representar uma inovação de soluções, porquanto síntese dos elementos multiformes que presidiam a expetiência jurídica portuguesa no período de afirmação do direito romano. Em termos de evolução histórica, todavia, os preceitos recolhidos na compilação publicada em nome de D. Afonso $\mathrm{V}$ possuem destacada importância. Deveras, no preciso diagnóstico de Mário Júlio de Almeida Costa, "as Ordenações Afonsinas assumem uma posição destacada na história do direito português. Constituem a síntese do trajecto que, desde a fundação da nacionalidade, ou, mais aceleradamente, a partir de Afonso III, afirmou e consolidou a autonomia do sistema jurídico nacional no conjunto peninsular. Além disso, representam o suporte da evolução subseqüente do direito português. Como se apreciará, as Ordenações ulteriores, a bem dizer, pouco mais fizeram do que, en momentos sucessivos, actualizar a coletânea afonsina. Embora não apresente uma estrutura orgânica comparável à dos códigos modernos e se encontre longe de oferecer uma disciplina juridica tendencialmente completa, trata-se de uma obra muito meritória quando vista na sua época. Nada desmerece em confronto com as compilações semelhantes de outros países" ${ }^{\text {"7n }}$. Outra sorte não lhe assiste, a propósito, no plano político, tendo em conta que, imediatamente, as Ordenações Afonsinas "resultavam da necessidade da afirmação nacional", consoante observa Pontes de Miranda ${ }^{71}$. Assim, também, a leitura de Mário Júlio de Almeida Costa: "a publicação das Ordenações A fonsinas liga-se ao fenómeno geral da luta pela centralização. Traduz esta colectânea jurídica uma espécie de equilíbrio das várias tendências ao tempo não perfeitamente definidas, ou seja, uma área intermédia em que ainda podiam encontrarse. De um outro ângulo, acentua-se a independência do direito próprio do Reino em

\footnotetext{
${ }^{68}$ História do Direito Português. Lisboa: Fundação Calouste Gulbenkian, 1985, p. 192, vol. I.

"História do Direito Português. Lisboa: Fundação Calouste Gulbenkian, 1985, p. 192, vol. I.

${ }^{70}$ História do Direito Português, 2. ed.. Coimbra: Almedina, 1992, p. 274.

"Fontes e Evolução do Direito Civil Brasieieiro, 2. ed.. Rio de Janeiro: Forense, 1981, p. 274.
} 
face do direito comum, subalternizado no posto de fonte subsidiária por mera legitimação da vontade do monarca"72.

As Ordenações Afonsinas constituíam-se em uma compilação de soluções jurídicas, sem qualquer pretensão de plenitude (típica das codificações racionalistas ${ }^{73}$, irremediavelmente conectada com a mentalidade continental de oitocentos ${ }^{74}$ ), com o que de logo tinham os juristas de então pensar em fontes jurídicas subsidiárias para operacionalização do direito em caso de lacunas e obscuridades das normas a fonsinas. A fonte precípua era o direito próprio do Reino (ley do Regno, Estilo ou Custume suso dito), sendo invocável, subsidiariamente, o direito comum (Leyx Imperiaaes, en assuntos temporais, e Santos Canones, em tena de pecado) e as glosas de Acúrsio e a opinião de Bartolo ("se o caso de que se trauta en pratica, nom fosse determinado per ley do Regno, on estilo, on custume suso dito ou Leyx Imperiaaes, ou Santos Canones, entom mandamos que se guardem as grosas d'Acursio encorporadas nas ditas Leys. E quando pelas ditas grosas o caso non for determinado, mandamos, que se guarde a opiniom de Bartholo, nö embargante que os outros Doutores diguam o contrario", Livro II, Título IX ${ }^{75}$ ), clara expressão da autoridade dos doutores que permeou todo o pensamento jurídico medieval ${ }^{7 / 6}$. Finalmente, tudo falhando, recorriase à autoridade régia para solução da cinca.

O problema do direito subsidiário em Portugal e a sua solução coloca-nos na contingência de identificar, já aqui, outro traço decisivo para compreensão das mais fundas raizes do direito brasileiro, segundo anota Judith Martins-Costa: o "bartolismo" . Com efeito, tendo em conta a lacunosidade das Ordenações c a própria imperfeição das normas de sobredireito ali recolhidas, natural que os julgadores se encontrassem na situação de buscar respostas aos problemas práticos na autoridade dos doutores (que, afinal, encarnavam a própria autoridade do Corpus Iuris Civilis, como repositório próprio de "todo o conjunto de saber possivel", consoante observa Antônio Castanheira Neves ${ }^{78}$, já que os juristas medievais viam no Corpus, nas glosas e nos comentátios, não apenas testemunhos bistóricos sobre dada realidade, mas a própria ratio scripta, a própria razão "convertida em palavra""s).

${ }^{72}$ História do Direito Português, 2. ed.. Coimbra: Almedina, 1992, pp. 274/275.

${ }^{73} \mathrm{Karl}$ Engisch, Introdução ao Pensamento Juridico, 8. ed.. Lisboa: Fundaçào Calouste Gulbentian, 2001, p. 206.

${ }^{74}$ Giovanni Tarello, Storia della Cultura Giuridica Modema. Bologna: Il Mulino, 1976, p. 19.

${ }^{75}$ Guarde-se o ponto: nas Ordenaçōes Afonsinas, assim como se dará nas Manuelinas, o problema do direito subsidiário vaí versado no Livro II, referente, entre outros assuntos, às coisas da Igreja. Adiante, buscar-se-á explorar o tema.

${ }^{76}$ Antônio Castanheira Neves, Metodologia Jurídica .. Problemas Fundamentais. Coimbra: Combra Editora, 1993 , p. 86.

${ }_{77}$ A Boa-Fé no Direito Privado, 1. ed., 2. tragem. São Paulo: Revista dos Tribunais, 2000, p. 241.

${ }^{73}$ Metodologia Juridica - Problemas Fundamentais. Coimbra: Coimbra Editora, 1993, p. 86.

79 Franz Wieacker, História do Direito Privado Modemo, 2. ed.. Lisboa: Fundaçăo Calouste Gulbenkian, 1993 , p. 49. 
Dessarte, o problema da sistematização do direito português fora solucionado pelas Otdenações Afonsinas. Outros, porém, estavam na hora do dia das preocupações lusitanas, dentre os quais o de maior envergadura eta o da divulgação do direito do Reino: este desiderato tocatia especificamente às Ordenações Manuelinas ${ }^{80}$. As Ordenações Manuelinas, pois, acometeu-se precipuamente a tarefa de tornar público e do conhecimento de todos o direito reinol, no que contou com a poderosa ajuda da descoberta da imprensa, que en Portugal aporta, ao que parece, $\operatorname{em} 1487^{81}$.

Em termos de estrutura, as Ordenações Manuelinas mantiveram o que já tínhamos com as Ordenações Afonsinas, registrando-se, no entanto, certa variação $\mathrm{em}$ seu conteúdo e o aporte de uma nova técnica legislativa. As disposiçôes legais referentes aos judeus, por exemplo, desapareceram, tendo em conta a expulsão dos mesmos do Reino, em 1496, assim como a autononização das normas fazendárias, que se excluíram das Ordenações principais para composição das Ordenações da Fazenda, em 1521. No que concerne à técnica legislativa, abandonou-se o estilo retrospectivo (mera transcrição de leis anteriores, com a indicação dos monarcas que as promulgaram), presente nas Ordenações de Afonso $\mathrm{V}$, em função da adoção de um estilo decretório, como se de normas novas se tratasse. De postremeiro, no que atine às soluções encampadas, não se registra qualquer transformação radical ou profunda em relação às Ordenações precedentes, mantendo-se, essencialmente, o direito anterior ${ }^{82}$.

Tal como se sucedeu a propósito das Ordenações Afonsinas, também no que toca às Ordenações Manuelinas sentiu-se a necessidade de regular o direito subsidiário. No âmbito destas, a solução da celeuma vinha proposta no Livro II, Título V, no que se manteve a primazia das fontes nacionais, seguida do recurso ao direito comum (romano e canônico, com a peculiaridade de que agora o direito romano deveria guardar-se pela boa razão em que é fundado), à glosa de Acúrsio e aos comentários de Bartolo (desde que não colidentes com a comum opinião dos doutores, caso em

so Assim, Nuno J. Espinosa Gomes da Silva, História do Direito Português. Lisboa: Fundação Calouste Gulbenkian, 1985 , p. 206, vol. I.

* Segundo Mário Júlio de Almeida Costa, além da preocupação com a dífusão do direito do Reino, também haveria contado para elaboração das Ordenações Manuelinas a vaidade de D. Manuel, então rei de Portugal. Com efeito, após indicar a hipótese alvitrada no texto, refere Mátio Júlio de Almeida Costa que "ainda se menciona outra aspecto. $O$ de que năo seria indiferente a D. Manuel, que assistju a pontos altos da gesta dos descobrimentos, ligar o seu nome a uma reforma legisiativa de vulto. A suposiçăo alicerça-se en vários testemunhos, inclusive na importância atribuida pelo rei ao direito e à realização da justiça" (História do Direito Português, 2. ed.. Coimbra: Almedina, 1992, pp. 277/278).

${ }^{2}$ Assim, Nuno J. Espinosa Gomes da Silva, História do Direito Português. Lisboa: Fundação Calouste Gulbenkian, 1985, pp. 209/210, vol. 1. 
que esta tinha primazia, outro dado novo em relação às Ordenações Afonsinas) e, por derradeiro, tudo gorando, buscava-se a autoridade régia ${ }^{33}$. Ainda aqui, pois, mantida a tradição bartolista, dado que os mesmos problemas que pontuavam as Ordenações Afonsinas continuaram a se insinuar pelas vestes das novas Ordenações.

O intento de compilar-se novamente o direito português nasce do elevado número de legislações esparsas posteriores ao arranjo manuelino, o que de certa maneira poderia infirmar a posição central das Ordenações, sobre dificultar o acesso à ordem jurídica do dia. Nestas paragens que se justifica a compilação filipina.

As Ordenações Filipinas datam de 1603, sendo que sobra patente do exame de seu conteúdo (essencialmente inalterado en relação às disposições manuelinas) que o desiderato legislativo cingia-se a uma "pura revisão actualizadora das Ordenações Manuelinas" $\$ 4$. Estruturalmente, manteve-se o esquema livros, títulos e parágrafos, observando-se o lastro de nossa cultura.

Quanto ao direito subsidiário, restou inalterado o esquema desenhado pelas Ordenações Manuelinas, tirante no que tocava à sua localização. Com efeito, antes albergado no Livro II das Ordenações precedentes, o problema do direito subsidiário vinha agora impostado no Livro III das Ordenações Filipinas, alocado na estrutura referente às cousas do então direito judiciário civil. Como observa Mário Júlio de Almeida Costa, "este último aspecto do enquadramento não parece fortuito. Na verdade, a referida transposição significa que o problema do direito subsidiátio deixou de ser disciplinado a propósito das relações entre a Igreja e o Estado (liv. II), deslocando-se para o âmbito do processo (liv. III). Ora, pode detectar-se aí, como salienta Braga da Cruz, a ruptura da 'última amarra' que ligava a questão do direito

43 A respeito da diferente conformaçăo que se opera no direito subsidiário das Ordenações Afonsinas para as Ordenações Manuelinas e Filipinas, escreve Mário Júlio de Almeida Costa: "cifram-se en duas as diferenças essenciats de conteúdo que separam no âmbito do direito subsidiatio, as Ordenações Manuelinas e as Ordenaçōes Filipinas do precedente texto afonsino. A saber: I-Quanto à aplicação dos textos de direito romano e de direito canônico, deixa-se de referir a distinção entre problemas jurídicos temporais e espirituais. Apenas se consagra o critério do pecado, que fornecia o único límite à prevalência subsidiária do direito romano sobre o direito canônico, qualquer que fosse a natureza do caso omisso. II -.. A respeito da Glosa de Acúrsio e da opinião de Bartolo, cuja ordem de precedência se conserva, estabelece-se o requisito de a 'comum opiniẫo dos doutores' não contrariar essas fontes. Relativamente a Bartolo, a restrição seria definida tão-só pelos autores que tivessem escrito depois dele. $O$ facto de a letra da lei colocar a 'communis opinio' como filtro da Glosa de Acúrsio e da opinião de Bartolo levou à interpretaçăo, posto que rảo pacífica, de que aquela constituía, err si mesma, uma fonte subsidiária. Por outras palaviass: na falta de direito nacional, de direito romano e de direito canônico, caberia recorrer à opinuão conum, antes da Glosa de Acúrsio e da opinião de Bartolo" (História do Direito Português, 2. ed.. Coimabra: Almedina, 1992, p. 311).

${ }^{84}$ Mário Júlio de Ameida Costa, História do Direito Português, 2. ed.. Coimbra: Almedina, 1992, p. 285. 
subsidiário à idéia anterior de um conflito de jurisdições entre o poder temporal e o poder eclesiástico, simbolizados, respectivamente, pelo direito romano e pelo direito canônico. Tornou-se, em suma, de acordo con a atitude da época, um puro e simples problema técnico-jurídico" ${ }^{185}$.

Buscando uma sintese da evolução histórica das fontes de direito no período das Ordenações, escreve Nuno J. Espinosa Gomes da Silva que "desde a entrada em vigor das Ordenações Afonsinas até ao fim do periodo que estudamos isto é, durante cerca de três séculos, se mantém um mesmo sistema de hierarquização das fontes, com a única alteração de se haver introduzido a communis opinio, tutelando a glosa de Acurrio e a Bártoli opinio. Pode, assim, dizer-se que, durante todo esse tempo, a matéria tempotal vai ser, praticamente, regida pelos direito português e romano; constituirá o direito português a regra, uma vez, no imperativo das Ordenações, só se deverá recorrer ao dircito comum, na falta de direito pátrio. Sabemos já, também, que o direito português, codificado nas várias Ordenações, não formava um todo orgânico, dado que fora legislado tendo como pressuposto a vigência do direito comum. De um modo geral, o rei legislara para esclarecer, ou contrariar regras de direito justinianeu: nomeadamente, no âmbito do direito privado, a lei nacional surgira como tomada de posição, frente ao direito comun. Deste modo, ao menos substancialmente, quase pode dizer-se que o direito romano constituíra a regra, e o pátrio, a excepção" ". Neste especial, o trabalho de colocar o manancial comum à bem do desenvolvimento da sociedade sobra destinado, em um primeiro momento, à doutrina (representado por Acúrsio e Bartolo e, depois, pela comum opinião dos doutores) e, logo en seguida, à jurisprudência, que acaba por funcionar como o grande elemento de evolução e estabilização do direito no periodo das Ordenações (pense-se, por exemplo, no papel dos assentos judiciários).

O processo civil desenhado nas Ordenações (tanto Afonsinas, como Mánuelinas e Filipinas) é um típico exemplo de processo comum ${ }^{87}$, forjado pela confluência dos elementos romano, canônico e germânico antigo. Suas soluções são soluções muitas vezes de força (como se percebe com bastante nitidez em alguns institutos, como, por exemplo, nas "cartas de segurança", com o vinco mandamental a toda prova ${ }^{88}$, Ordenações Filipinas, Livro V, Título CXXVIII), com adiantamento de execução à cognição (como nas nossas antigas ações cominatórias, também conhecidas como "ação de embargos à primeira" ${ }^{89}$, Ordenações Filipinas, Livro II,

${ }^{85}$ História do Direito Português, 2. ed.. Coimbra: Almedina, 1992, p. 310.

* História do Direito Português. Lisboa: Fundaçăo Calouste Gulbenkian, 1985, p. 254, vol. I.

${ }^{87}$ Assim, Enrico Tullio Liebman, "1l Nuovo 'Codigo de Processo Civil' Brasiliano". In: Problemi del Processo Civile. Napoli: Morano Editore, 1962, p. 483.

${ }^{8}$ Sobre o assunto, Ovídio Aratijo Baptista da Silva, Curso de Processo Civil, 4. ed.. São Paulo: Revista dos Tribunais, 2000 , pp. 34\%/351, vol. II.

3n Acerca, Pontes de Miranda, Comentários ao Código de Processo Civil, 2. ed. Rio de Janeiro: Revista Forense, 1959, pp. 5/12, tomo V. 
Título LXXVIII, $\left(5^{\circ}\right)$, atitude típica do direito germânico mais temoto, nada obstante a firmeza da concepção de juízo como uñ ato de três pessoas (Ordenações Afonsinas, Livro III, Título XX, $\$ 1^{\circ}$ ), a denotar a fiel observância do contraditório e da imparcialidade na decisão da causa, herança induvidosamente romana, e o tom conciliatório agregado à figura judicial (Ordenações Manuelinas, Livro III, Título XV, $\$ 1 \%$, de corte canônico. O procedimento era secreto e escrito, essencialmente dominado pelos princípios da demanda e dispositivo, com certa proeminência do autor en telação ao juízo (tanto que chamado em determinadas oportunidades de "Senhor do Preito" pelas Ordenações, por exemplo, Afonsinas, Livro III, Título XXIII), dividido em fases bem distintas (sistema de preclusão por fases, com larga adoção das técnicas da eventualidade e da concentração), rigidamente regrado com relação à formação da prova ${ }^{0}$. A racionalidade que informava o fenômeno jurídico era uma racionalidade prática, voltada a orientar a ação dos sujeitos envolvidos na dialética processual ${ }^{\text {g11 }}$, pronta para resolução das questões postas para discussão ${ }^{92}$.

Neste especial, a propósito, cumpre assinalar a primeira particularidade que singulariza a experiência jurídica brasileira: até o advento do Código de Processo Civil vigente, o nosso direito processual civil não havia sofrido nenhum acidente histórico notável, capaz de propiciar um distanciamento mais profundo entre a tradição lusitana quinhentista e o direito então praticado ${ }^{93}$ (livramo-nos por certo, da "radical renovação dos princípios de direito processual" ${ }^{4}$ propiciada pelo Code de Procédure Civile napoleônico de 1806 que apanhou o direito continental com toda a sua força: vale dizer, conseguimos adiar a invasão francesa para 1973, dando maior espaço para o desenvolvimento natural de nossa tradição cultural). Como é cediço, mesmo após a nossa independência continuaram a ter vigência no Brasil as Ordenações Filipinas, sendo que o processo civil brasileiro só fora alcançado por legislação nacional quando o Decreto n. 763 , de 1890 , mandou que se aplicasse ao foro cível o Regulamento n.

sy Sobre o assunto, Carlos Alberto Alvaro de Oliveira, Do Formalismo no Processo Civil, 2. ed.. São Paulo: Saraiva, 2003, pp. 30/33.

$"$ Acerca, Antônio Castanheira Neves, Metodologia Juridica - Problemas Fundamentais. Coimbra: Coimbra Editora, 1993, p. 87.

92 O processo, então, era visto sobretudo como un método para solução de questöes, conforme Giuseppe Chiovenda, Instituiçōes de Difeito Processual Civil, 3. ed.. São Paulo: Saraiva, 1969, P. 127, vol. 1 .

${ }^{93}$ Neste serticlo, assinala Enrico Tullio Liebman que o direjto brasileiro restou infenso à grande fratura produzida no direito europeu em função da influência francesa, dos Códigos Napoleônicos, o que the possibilitou uma evolução histórica linear, sem maiores rupturas (conforne "Istituti del Dirito Comune nel Processo Civile Brasiliano". In: Problemi del Processo Civile. Napoli: Morano Editore, 1962, pp. 498/502). Neste sentido, ainda, Carlos Alberto Alvaro de Oliverra, Do Formalisno no Processo Civil, 2. ed.. São Paulo: Saraiva, 2003, p. 33.

${ }^{94}$ Franz Wieacker. História do Direito Privado Moderno, 2. ed.. Lisboa: Fundaçäo Calouste Gubenkian, 1993, p. 7. 
737, de 1850 (que, nada obstante tenha procurado simplificar algumas formas, manteve basicamente a estrutura do processo, particularizando-se apenas por aportar: uma nova técnica legislativa à ordem jurídica nacional ${ }^{15}$ ). Antes, a Consolidação Ribas, aprovada por Resolução Imperial de 1876, havia apenas recolhido o direito lusobrasileiro então aplicável à praxe forense, tornando-o mais facilmente identificável ${ }^{96}$. Neste panorama, o papel da doutrina fora enome: cumpria-lhe subsidiar a aplicação do direito luso-brasileiro, então lacunoso e imperfeito, sobre indicar soluções mais rentes à ordem do dia, quiçá alçando mão do direito comparado e da autoridade de doutrinadores estrangeiros (aqui, a manifestação de nosso "bartolismo", de que há pouco falávamos, deveras impregnado em nossa tradição jurídica ${ }^{97}$ ).

O Código de Processo Civil de 1939, a que se chegou depois de um certo período em que tivemos inúmeros Códigos estaduais na matéria (pluralismo que só poderia ter fracassado, tendo em conta o nosso acentuado centralismo jurídico), mesclava alguns elementos modernos com institutos tipicamente pertencentes ao direito intermédio. Informado pela técnica da oralidade, o legislador de 1939 imprimiu ao processo um nítido sabor publicístico, outorgando ao juiz o encargo de dirigi-lo com o fito de alcançar ao povo justiça pronta e eficaz. A anunciada síntese entre romanismo e germanismo, base do processo civil moderno, segundo conhecida lição de Giuseppe Chiovend $a^{98}$, estava então a manifestar-se, ainda que de maneira tínida, limitada basicamente à primeira parte daquele diploma (única, consoante Alfredo Buzaid", elaborada à luz dos "princípios modernos da ciência do processo", na qual Buzaid, ao nosso ver equivocadamente, identificava inclusive a existência de um verdadeiro "processo de conhecimento"), com o que ainda se poderia vislumbrar no processo civil de então nítidos traços do processo comum lusombrasileiro ${ }^{\text {nọ }}$.

Com efeito, desde nossas mais fundas raízes experimentávamos o praxismo como modelo processual. Esse quadro só veio a alterar-se com o Código de Processo

95 Assim, Enrico Tullio Liebman, "Istituti del Dixitto Comune nel Processo Civile Brasiliano". In: Problemi del Processo Civile. Napoli: Morano Editote, 1962, p. 500 . Sobre o assunto, mais extensamente, Carlos Alberto Alvaro de Oliveiza, Do Formalismo no Processo Civil, 2. ed.. São Paulo: Saraiva, 2003, pp. 44/46; José da Silva Pacheco, Evolução do Processo Civil Brasileiro, 2. ed.. Rio de Janeiro: Renovar, 1999, pp. 128/131.

\% Acerca, José da Silva Pacheco, Evolução do Processo Civil Brasilciro, 2. ed.. Rio de Janeiro: Renovar, 1999, pp. 132/135.

"7 Acerca, Judith Marcins-Costa, A Boa-Fé no Direito Privado, 1. ed., 2, tiragem. São Paulo: Revista dos Tribunais, 2000 , pp. 241/246.

9s "Romanesimo e Germanesimo nel Processo Civile". In: Saggi di Diritto Processuale Civile.

Roma: Società Editrice "Foro Italiano", 1930, pp. 181/224, vol. l.

"Exposição de Motivos. Brasilia, 1972, ns. 3 e 4.

${ }^{300}$ Conforme o clássico estudo de Enrico Tullio Liebman, "Istituti del Dirito Comune nel Processo Civile Brasiliano". In: Problemi del Processo Civile. Napoli: Morano Editore, 1962, Pp. 502/516. 
Civil de 1973, diplomá normativo que inaugurou entre nós, inequivocamente, o processualismo, impondo um método científico ao processo civil à força de construções alimentadas pela lógica teórico-positiva, evadindo-o da realidade. Enxertando em nossa tradição elementos estranhos à mesma (pense-se, por exemplo, na positivação de um "Processo de Conhecimento" seguido, no mais das vezes, de um rígido "Processo de Execução"), não surpreende que suas linhas mestras tenham gorado en menos de trinta e poucos anos mercê de sucessivas teformas, que pouco mais fizeram além de resgatar algo que era próprio e peculiar à nossa cultura, ainda que em um outro nivel de compreensão (pense-se na "nova" disciplina das ações cominatórias, art. 287, CPC, nuito semelhante a que tínhamos a propósito no regime das Ordenações, e na positivação de tutelas interditais, arts. 273, 461 e 461-A, CPC).

É nesse ambiente que se chega ao formalismo no Brasil, como modelo processual próprio do momento que ora se vive. Superado aquele estágio anterior de exacerbação técnica, de vida legal breve entre nós, recobra-se a consciência de que o processo está aí para concretização de valores, não sendo estranho à função do juiz a consecução do justo, tanto que se passa a vislumbrar, no processo, o escopo de realizar a justiça no caso concreto ${ }^{\text {in1 }}$, convocando-se una racionalidade prática para condução do debate judiciário. Majs: a tomada de consciência de que a força normativa da Constituição deve alcançar todo o direito processual civil, não sendo esse outra coisa que não o próprio direito constitucional aplicado ${ }^{102}$, fez acentuar os poderes do juiz na relação jurídica processual, armando-o de técnicas capazes de proporcionar ao jurisdicionado o efetivo acesso à ordem jurídica justa, sobrando evidente que, nesse panorama, o próprio conceito de juris dição transforma-se sobremaneira, consoante

101 Neste sentido, Carlos Aberto Alvaro de Oliveira, "O Processo Civil na Perspectiva dos Direito Fundamentais". In: Alvaro de Oliveira, Carlos Aberto (o:g.), Processo e Constituiçào. Rio de Janeiro: Forense, 2004, p. 12. Ainda assim, Daniel Francisco Mitidiero, Comentários ao Código de Processo Civil. São Paulo: Memória Jurídica Editora, 2004, p. 16, tomo 1 .

102 Explorando as relaçôes entre Constituição e Processo Civil, consulte-se, entre outros, na doutrina brasileira, Carlos Alberto Alvaro de Oliveira, Do Formalismo no Processo Civil, 2. ed.. São Paulo: Saraiva, 2003, pp. 106/108; "O Processo Civil na Perspectiva dos Direitos Fundamentais". In: Alvaro de Oliveira, Carlos Alberto (org), Processo e Constituiçăo. Rio de Janeiro: Forense, 2004, pp. 1/15; Luiz Guilherne Marinoni, Técnica Processual e Tutela dos Direitos. São Paulo: Revista dos Tribunais, 2004, pp. 165247; Hermes Zaneti Júnior, "Processo Consutucional: Relaçóes entre Processo e Constituição". In: Introdução ao Estudo do Processo Civil - Primeiras Linhas de um Paradigma Emergente. Porto Alegre: Sérglo Antonnio Fabris Editor, 2004, pp. 23/62, em comautoria con Daniel Francisco Mitidiero; na doutrina estrangeira, entre outros, Enrico Tullio Liebman, "Diritto Costuzionale e Processo Civile". In: Problemi del Processo Civile. Napoli: Morano Lditore, 1962, pp. 149/154; Eduardo Juan Couture, "Las Gamantías Constitucionales del Proceso Civil". In: Estudios de Derecho Procesal Civil. Buenos Arres: Ediar Editores, 1948, pp. 19/95, tomo I; Nicolò Trocker, Processo Civile e Costituzione. Milano: Giuffre, 1974; Luigi Paolo Comogho, La Garanzia Costituzionale dell'Azione ed if Processo Civile, Padova: Cedam, 1970. 
já tivemos a oportunidade de registrar alhures ${ }^{103}$. A Constituição de 1988 imprimiu o método instrumentalista, próprio do formalismo, bem aproveitando a doutrina o ambiente cultural propício para transformação de nosso processo civil.

\section{IV - À Guisa de Conclusões: sobre Leões e Castelos}

Ante o que se pôde brevemente expor, sobram alguns pontos que merecem, a olhos vistos, uma mais apurada reflexão, empresa que se pretende levar a cabo em breve. $O$ que nos parece fundamental, porém, já se pode assentar desde logo: que o direito pertence à cultura e que todos nós, brasileiros, somos filhos de Leão e Castela, somos filhos de uma longeva tradição cultural que nos singulariza ençuanto povo. Vale dizer: o nosso processo civil tem identidade própria e características que the são peculiares, não podendo furtar-se o intelectual brasileiro de levar em consideração as nossas raízes no quando da análise de nossas instituiçòes. Oxalá que não percamos o rico sentido histórico do processo civil brasileiro.

\section{REFERENNCIAS BIBLIOGRÁFICAS}

ALMEIDA COSTA, Mário Júlio de, "Fundamentos Históricos do Direito Brasileiro". In: Estudos de Direito Civil Brasileiro e Português (I Jornada Luso-Brasileira de Direito Civil). São Paulo: Revista dos Tribunais, 1980.

. História do Direito Português, 2. ed.. Coimbra: Almedina, 1992.

ALVARO DE OLIVEIRA, Carlos Alberto. Do Formalismo no Processo Civil, 2. ed.. São Paulo: Saraiva, 2003.

. "O Problema da Eficácia da Sentença". In: Revista Gênesis de Direito Processual

Civil. Curitiba: Gênesis, 2003, n. 29.

"O Processo Civil na Perspectiva dos Direitos Fundamentais". In; ALVARO DE

OLIVEIRA, Catios Alberto (org), Processo e Constituição. Rio de Janeiro: Forense, 2004. AZEVEDO, Luiz Carlos de; CRUZ E TUCCI, José Rogério. Liçôes de História do Processo

Civil Romano, 1. ed., 2. tiragem, São Paulo: Revista dos Tribunais, 2001.

BAPTISTA DA SILVA, Ovídio Ataújo. Procedimentos Especiais -- Exegese do Código de Processo Civil (arts. 890 a 981). Rio de Janeiro: Aide Editora, 1993.

. Jurisdição e Execução na Tradição Romano-Canônica, 2. ed.. São Paulo; Revista dos Tribunais, 1997.

Curso de Processo Civil, 4. ed.. São Paulo: Revista dos Tribunais, 2000, vol. II. - Sentença e Coisa Julgada, 4. ed. Rio de Janeiro: Forense, 2003.

BARBOSA MOREIRA, José Carlos. "A Sentença Mandamental - Da Alernanha ao Brasil". In: Temas de Direito Processual. São Paulo: Saraiva, 2001, Sétima Série.

BAUR, Fritz. "Il Processo e le Correnti Culturali Contemporanee". In: Rivista di Diritto Processuale. Padova: Cedam, 1972, vol, XXVII.

193 Daniel Francisco Mitidiero, Comentários ao Código de Processo Civil. São Paulo: Memória Jurídica Editora, 2004, pp. 26/61, tomo I. 
BECKER, L. A.; SANTOS, E. L. Silva. Elementos para uma Teoria Crítica do Processo. Porto Alegre: Sérgio Antônio Fabris Editor, 2002.

BUZAID, Alfredo. Exposiçäo de Motivos. Brasilia, 1972.

CAETANO, Marcello. História do Direito Português (1140-1495), 2. ed.. Lisboa: Editorial Verbo, 1985.

CALAMANDREI, Piero. "Istituzioni di Diritto Processuale Civile". In: Opere Giuridiche. Napoli: Morano Editore, 1970, vol. IV.

CALASSO, Francesco. Medio Evo del Diritto. Milano: Giuffrè, 1954, vol. I.

CAMPITELLI, Adriana. "Processo Civile (Dirito Intermedio)". In: Enciclopedia del Diritto. Milano: Giuffè, 1987, vol. XXXVI.

CASTANHEIRA NEVES, Antônio. Metodologia Jurídica - Problemas Fundamentais. Coimbra: Coimbra Editora, 1993.

CHIOVENDA, Giuseppe. "Romanesimo e Germanesimo nel Processo Civile". In: Saggi di Diritto Processuale Civile. Roma: Società Editrice "Toro Italiano", 1930, vol. I.

. Instituições de Direito Processual Civil, 3. ed.. São Paulo: Saraiva, 1969, vol. I.

COMOGLIO, Luigi Paolo. La Garanzia Costituzionale dell'Azione el il Processo Civile. Padova: Cedam, 1970.

COUTURE, Eduardo Juan. "Las Garantias Constitucionales del Proceso Civil". In: Estudios de Derecho Procesal Civil. Buenos Aires: Ediar Editores, 1948, tomo I.

CRUZ E TUCCI, José Rogétio; AZEVEDO, Luiz Carlos de. Lições de Histónia do Processo Civil Romano, 1. ed., 2. tragem. São Paulo: Revista dos Tribunais, 2001.

DENTI, Vittorio. "Diritto Comparato e Scienza del Processo". In: Rivista di Diritto Processuale. Padova: Cedam, 1979, vol. XXXIV.

- "Valori Costituzionali e Cultura Processuale". In: Rivista di Diritto Processuale. Padova: Cedam, 1984, vol. XXXIX.

DINAMARCO, Cândido Rangel. A Instrumentalidade do Ptocesso, 8. ed.. São Paulo: Malheiros, 2000. tomo I.

. Fundamentos do Processo Civil Moderno, 4. ed.. São Paulo: Malheiros, 2001,

. Fundamentos do Processo Civil Moderno, 4. ed.. São Paulo: Malheiros, 2001, tomo II.

. Instituições de Direito Processual Civil, 3. ed.. São Paulo: Malheiros, 2003, vol. l.

ENCISCH, Karl. Introdução ao Pensamento Juridico, 8. ed.. Lisboa: Fundação Calouste Guberkian, 2001.

FAZZALARI, Elio. Istituzioni di Diritto Processuale. Padova: Cedam, 1975.

GOMES DA SILVA, Nuno J. Espinosa. Histótia do Direito Português. Lisboa: Fundação Calouste Gulbenkian, 1985, vol. I.

HOLANDA, Sérgio Buarque de. Raizes do Brasil, 26. ed., 17. tiragem. São Paulo: Companhia das Letras, 2003.

KASER, Max. Direito Privado Romano. Lisboa: Fundação Calouste Gulbentian, 1999.

KOSCHAKER, Paul. Europa y el Derecho Romano. Madrid: Editorial Revista de Derecho Privado, 1955.

LACERDA, Galeno. "Processo e Cultura". In: Revista de Direito Processual Civil. São Paulo: Saraiva, 1961, vol. III.

. Comentários ao Código de Processo Civil, 7. ed.. Rio de Janeiro: Forense, 1998, vol. VIII, tomo I.

LIEBMAN, Enrico Tullio "Diritto Costituzionale e Processo Civile". In: Problemi del Processo Civile. Napoli: Morano Editore, 1962. 
" "Il Nuovo "Codigo de Processo Civil' Brasiliano". In: Problemi del Processo Civile. Napoli: Morano Editore, 1962.

" "Istituti di Diritto Comune nel Processo Civile Brasiliano". In: Problemi del Processo Civile. Napoli: Morano Editore, 1962.

MARINONI, Luiz Guilherme. Novas Linhas do Processo Civil, 4. ed.. São Paulo: Malheiros, 2000 .

Técnica Processual e Tutela dos Direitos. São Paulo: Revista dos Tribunais, 2004. MARTINS-COSTA, Judith. A Boa-Fé no Direito Privado, 1. ed., 2. tiragem. São Paulo: Revista dos Tribunais, 2000.

MITIDIERo, Daniel Francisco. Comentários no Código de Processo Civil. Sào Paulo: Memória Juridica Editora, 2004, tomo I.

MITIDIERO, Daniel Francisco; ZANETI JUNNIOR, Hermes. Introdução ao Estudo do Processo Civil - Primeiras Linhas de um Paradigma Emergente. Porto Alcgre: Sérgio Antônio Fabris Editor, 2004.

PACHIsCO, José da Silva. Evolução do Processo Civil Brasileiro, 2. ed.. Rio Je Janeiro: Renovar, 1999.

PICARDI, Nicola. "Processo Civile (Diritto Moderno)". In: Enciclopedia del Diritto. Milano: Giuffrè, 1987, vol. XXXVI.

PONTES DE MIRANDA, Fancisco Cavalcanti. Comentários ao Código de Processo Civil, 2. ed.. Rio de Janeiro: Revista Forense, 1959, tomo V.

- Tratado das Ações. São Paulo: Revista dos Tribunais, 1970, tomo I.

- Tratado das Ações. São Paulo: Revista dos Tribunais, 1976, tomo VI.

. Fontes e Evolução do Direito Civil Brasileiro, 2. ed.. Rio de Janeiro: Forense, 1981. tomo I.

Comentários ao Código de Processo Civil, 5. ed.. Rio de Janeiro: Forense, 1997, . Comentários ao Código de Processo Civil, 2. ed.. Rio de Janeiro: Forense, 2004, tomo XIII.

REALE, Miguel. "Para uma Teoria dos Modelos Jurídicos". In: Estudos de Filosofia e de Ciência do Direito. São Paulo: Saraiva, 1978.

- Liçōes Prelirninares de Direito, 23. ed.. São Paulo: Saraiva, 1996.

SANTOS, E. L. Silva; BECKER, L. A. Elementos para uma Teoria Crítica do Processo. Porto Alegre: Sérgio Antônio Fabris Fditor, 2002.

TALAMANCA, Matio. "Processo Civile (Diritto Romano)". In: Enciclopedia del Diritto. Milano: Giuffrè, 1987, vol. XXXVI.

TARELLO, Gioyanni. Storia della Cultura Giuridica Moderna. Bologna: Il Mulino, 1976. TROCKER, Nicolò. Processo Civile e Costituzione. Milano: Giuffrè, 1974.

WEBER, Max. Economia e Sociedade. Brasilia: Editora Universidade de Brasilia, 1999, vol. II. WIEACKER, Franz. História do Direito Privado Moderno, 2. ed.. Lisboa: Fundação

Calouste Gulbenkian, 1993.

ZANETI JÚNIOR, Hetmes. Mandado de Segurança Coletivo - Aspectos Processuais Controversos. Porto Alegre: Sérgio Antônio Fabris Editor, 2001.

ZANETI JÚNIOR, Hermes; MITIDIERO, Daniel Francisco. Introdução ao Estudo do Processo Civil - Primeiras Linhas de un Paradigma Enmergente. Porto Alegre: Sérgio Antônio Fabris Editor, 2004. 